ISSN 1678-3921

Journal homepage: www.embrapa.br/pab

For manuscript submission and journal contents, access: www.scielo.br/pab
Rafael Ferreira Montes ${ }^{(1 凶)}$ (iD,

Flávio Breseghello(2) (iD and

João Batista Duarte(1) (D)

(1) Universidade Federal de Goiás, Escola de Agronomia, Avenida Esperança s/non, CEP 74690-900 Goiânia, GO, Brazil. E-mail: rafael.fmontes@gmail.com, jbduarte@ufg.br

(2) Embrapa Arroz e Feijão, Rodovia GO-462, Km 12, CEP 75375-000 Santo Antônio de Goiás, GO, Brazil.

E-mail: flavio.breseghello@embrapa.br

$\bowtie$ Corresponding author

Received

January 15, 2021

Accepted

August 26, 2021

How to cite

MONTES, R.F.; BRESEGHELLO, F.; DUARTE, J.B. Modelling of genotype by environment interaction to improve the recommendation of sugarcane cultivars for the state of Goiás, Brazil. Pesquisa Agropecuária Brasileira, v.56, e02398, 2021. DOI: https://doi.org/10.1590/ S1678-3921.pab2021.v56.02398.

\section{Modelling of genotype by environment interaction to improve the recommendation of sugarcane cultivars for the state of Goiás, Brazil}

\begin{abstract}
The objective of this work was to identify environmental factors with significant effects on the genotype by environment interaction (GEI) of sugarcane, and to generate thematic maps yield adaptability of genotypes for the state of Goiás, Brazil, through the integrated use of factorial regression models and the geographic information system (GIS). The study was based on the yield of recoverable sugar (YRS) from cultivar field trials carried out in nine locations. Fourteen environmental factors were used, out of which 11 were divided into 10 crop growth phases, totaling 113 environmental covariates (ECs). The selection of ECs was done by successive simple linear regressions, and the respective genotypic sensitivity coefficients were used to generate adaptability maps. Approximately $57 \%$ of the GEI effects were related to the covariates longitude, average temperature at crop germination phase, and maximum temperature at the beginning of the phase of greatest growth. For YRS, the RB034128 and RB034021 clones show specific yield adaptations, and the RB034045 cultivar can share the growing area with the RB867515 check cultivar.
\end{abstract}

Index terms: Saccharum, environmental covariates, multi-environment trials, sugarcane, yield adaptability.

\section{Modelagem da interação entre genótipo e ambiente para a melhoria da recomendação de cultivares de cana-de- açúcar para o estado de Goiás, Brasil}

\begin{abstract}
Resumo - O objetivo deste trabalho foi identificar fatores ambientais com efeitos significativos sobre a interação entre genótipos e ambiente (GEI), em canade-açúcar, e produzir mapas temáticos quanto à adaptabilidade produtiva de genótipos para o estado de Goiás, Brasil, por meio do uso integrado de modelos de regressão fatorial e do sistema de informação geográfica (SIG). O estudo foi baseado na produção de açúcar recuperável (ATR), obtida de ensaios de cultivares em campo, em nove localidades. Foram utilizados 14 fatores ambientais, dos quais 11 foram divididos em 10 fases de crescimento da cultura, no total de 113 covariáveis ambientais (ECs). A seleção de ECs foi feita por sucessivas regressões lineares simples, e os respectivos coeficientes de sensibilidade genotípica foram usados para produzir os mapas de adaptabilidade. Aproximadamente $57 \%$ dos efeitos da GEI estiveram relacionados às covariáveis longitude, temperatura média na fase de brotação da cultura e temperatura máxima no início da fase de maior crescimento. Para ATR, os clones RB034128 e RB034021 apresentam adaptações produtivas específicas, e a cultivar RB034045 pode compartilhar a área de cultivo com a cultivar-testemunha RB867515.
\end{abstract}

Termos para indexação: Saccharum, covariáveis ambientais, ensaios multiambientes, cana-de-açúcar, adaptabilidade produtiva. 


\section{Introduction}

The efficiency of sugarcane farming systems could be increased by matching genotypes adapted to specific environmental conditions with different growing locations. Such approach assumes that genotypes are differentially affected by environmental factors, which is a biological phenomenon known as genotype by environment interaction (GEI).

GEI can be modelled and interpreted by linear, bilinear, and linear-bilinear models (Malosetti et al., 2013; van Eeuwijk et al., 2016), mixed-effect models (Malosetti et al., 2013; van Eeuwijk et al., 2016), factorial regression models (van Eeuwijk et al., 1996), and crop growth models (van Eeuwijk et al., 2016).

The exploitation of the positive effects of GEI can be facilitated by understanding the main environmental factors involved. However, approaches that dissect the causes of this phenomenon using explicit environmental covariates have not been fully used worldwide (van Eeuwijk et al., 2016).

Most of the GEI studies on sugarcane focused on identifying mega-environments (Todd et al., 2018), similarity of test sites for selection (Guilly et al., 2017), and genotypic stability (Silveira et al., 2013). However, these empirical approaches do not take into account the environmental factors, which allows of a limited biological interpretation of GEI. The importance of analytical approaches integrating environmental factors have been well recognized (Ramburan et al., 2011, 2012).

Historically, GEI studies associated with environmental factors were hindered by the lack of environmental data associated with multi-environment trials (Xu, 2016). More recently, a range of climatic, topographic, and vegetation data sets became freely available (Hyman et al., 2013), opening opportunities to study the factors driving the differential response of genotypes across environments. Furthermore, it opened new frontiers for breeding programs to improve the process of germplasm testing and cultivar recommendation based on geographic information system (Annicchiarico et al., 2006; Resende et al., 2020; Costa-Neto et al., 2020).

Factorial regression (FR) models can be used for modeling GEI, incorporating information related to genotypes and/or environments in the analysis of multi-environmental trials (METs) (van Eeuwijk et al., 1996). This approach was successfully applied to the analyses of rice METs (Costa-Neto et al., 2020), sugarcane (Ramburan et al., 2011, 2012), and wheat (Vargas et al., 1999). Those models allow of GEI to be partially explained by the coefficients of genotypic-sensitivity to some environmental factors (for instance, rainfall and temperature), quantifying the influence of those factors on GEI, thus conferring biological meaning to the differences in the adaptation of genotypes to different sites.

Additionally, FR models can derive estimates of the genotype expected performance in nontested sites, based on geographic gradients. These techniques were applied in rice for a wide range of environments in Brazil, showing that approximately $59 \%$ of GEI effects were related to known environmental factors (Costa-Neto et al., 2020). With this information, it was possible to describe the reaction norm of genotypes for a geographic gradient, through informative maps of yield adaptability.

Goiás state is currently the second largest sugarcane producer among Brazilian states and has a great potential for area expansion (Manzatto et al., 2009). Therefore, it is important to study the distribution of yield adaptability and GEI effects on sugarcane across the geographic gradients in this state. Moreover, this approach can enable matching genotypes to specific sub-regions, in order to capitalize on the GEI effects into the performance of improved cultivars at growing fields.

The objective of this work was to identify environmental factors with significant effects on the genotype by environment interaction of sugarcane, and to generate thematic maps yield adaptability of genotypes for the state of Goiás, Brazil, through the integrated use of factorial regression models and the geographic information system (GIS).

\section{Materials and Methods}

The phenotypic data set used in the present work was based on test genotypes and check cultivars at the final assessment phase (multi-environmental trials - METs) of the sugarcane (Saccharum spp.) breeding program at Universidade Federal de Goiás (PMGCA/UFG), which is part of an inter-university network for the development of the sugarcane industry (Ridesa, 2021).

METs were conducted in nine production sites in the state of Goiás, during the 2011/2012 crop season 
(Table 1). The trials were designed as randomized complete blocks, with four replicates, in plots with two $20 \mathrm{~m}$ rows, spaced at $1.5 \mathrm{~m}$, except for the UCA site, where plots were five $8 \mathrm{~m}$ rows. Approximately 30 genotypes (the best clones from the previous selection phases) were tested per trial, totaling 45 genotypes. However, only 26 genotypes grown in at least eight locations were used in the statistical analyses of this study, as follows: RB034004, RB034021, RB034038, RB034041, RB034044, RB034045 (cultivar), RB034067, RB034068, RB034070, RB034109, RB034110, RB034111, RB034113, RB034114, RB034116, RB034117, RB034120, RB034122, RB034125, RB034127, RB034128, RB034130, RB034131, RB034132, RB867515, and SP81 3250 (the last two genotypes are checks cultivars).

The trait of interest was the yield of recoverable sugar (YRS, $\mathrm{Mg} \mathrm{h}^{-1}$ ) corresponding to the product of the stalk yield by the estimated recoverable sugar. The latter is a function of the sucrose, nonsucrose, and fiber content, measured on a sample of 10 culms from each plot. The measurements were obtained from plant-cane crop stage for all locations, except for UCA where it was measured in the first ratoon crop.

Analyses of variance for single-trials were carried out by fitting the following ordinary model of leastsquares (OLS)

$\mathrm{Y}_{\mathrm{ik}}=\mu+\mathrm{b}_{\mathrm{k}}+\mathrm{g}_{\mathrm{i}}+\varepsilon_{\mathrm{ik}}$

where: $Y_{i k}$ is the observed value for the plot with genotype $\mathrm{i}(\mathrm{i}=1,2, \ldots, \mathrm{g})$, at block $\mathrm{k} ; \mu$ is the overall mean; $b_{k}$ is the block effect $k$; $g_{i}$ is the genotype effect $\mathrm{i} ; \varepsilon_{\mathrm{ik}}$ is the random error on the plot, assumed as $\varepsilon_{\mathrm{ik}} \sim \mathrm{N}\left(0, \sigma^{2}\right)$. From fitting this model, adjusted means for each genotype at each trial were obtained.

Homogeneity of residual variances was confirmed by the $F_{\max }$ test (Pimentel-Gomes, 2009). The joint analysis followed the fixed model

$\bar{Y}_{i j}=\mu+g_{i}+e_{j}+(g e)_{i j}+\bar{\varepsilon}_{i j}$

where: $\bar{Y}_{i j}$ is the mean response of the genotype $i$ in the environment $j ; \mu$ is the overall mean; $g_{i}$ is the genotype effect $i$; $e_{j}$ is the environment effect $j$ $(\mathrm{j}=1,2, \ldots, \mathrm{a}) ;(\mathrm{ge})_{\mathrm{ij}}$ is the interaction between genotype $\mathrm{i}$ and environment $\mathrm{j} ; \bar{\varepsilon}_{\mathrm{ij}}$ is the pooled experimental error, with $\bar{\varepsilon}_{\mathrm{ij}} \sim \mathrm{N}\left(0, \sigma_{\mathrm{e}}^{2}\right)$. From the equation 2 , the (ge $)_{\mathrm{ij}}$ effects were estimated by OLS $(\hat{\mathrm{ge}})_{\mathrm{ij}}=\overline{\mathrm{Y}}_{\mathrm{ij}}-\overline{\mathrm{Y}}_{\mathrm{i} .}-\overline{\mathrm{Y}}_{\mathrm{j}}$ $+\bar{Y}_{. .,}$where $\bar{Y}_{\mathrm{ij}}, \bar{Y}_{\mathrm{i} .},-\overline{\mathrm{Y}}_{\mathrm{j}, \mathrm{y}}$, and $\overline{\mathrm{Y}}_{. .}$are, respectively, the mean of genotype i for the location $j$, mean of genotype $\mathrm{i}$ across locations, mean of location $\mathrm{j}$ across genotypes, and overall mean.

Statistical analyses and GIS tools were performed with the R platform (R Core Team, 2016), using mainly the packages tidyverse (Wickham et al., 2019) for data cleaning, stats to fit all models, and doBy (Højsgaard \& Halekoh, 2016) to compute the least-squares means. In addition, packages such as raster (Hijmans, 2016), rasterVis (Lamigueiro \& Hijmans, 2016), rnaturalearth (South, 2017), nasapower (Sparks, 2018), and tidyverse (Wickham et al., 2019) were used for reading, writing, graphical visualization, and manipulating of spatial data.

Data for 11 environmental factors - rainfall $(\mathrm{mm}$ $\left.\mathrm{d}^{-1}\right)$, relative humidity $\left(\% \mathrm{~d}^{-1}\right)$, earth skin temperature

Table 1. Location, planting and harvesting dates, geographic coordinates, and altitude of the trial sites, in the state of Goiás, Brazil.

\begin{tabular}{|c|c|c|c|c|c|c|c|}
\hline \multicolumn{3}{|c|}{ Location } & \multirow{2}{*}{$\begin{array}{c}\text { Planting } \\
\text { date }\end{array}$} & \multirow{2}{*}{$\begin{array}{l}\text { Harvesting } \\
\text { date }\end{array}$} & \multicolumn{2}{|c|}{ Coordinate } & \multirow{2}{*}{$\begin{array}{l}\text { Altitude } \\
(\mathrm{m})\end{array}$} \\
\hline Code & Plant & Municipality & & & Longitude & Latitude & \\
\hline UNA & Nardini mill & Aporé & $10 / 03 / 2011$ & $10 / 09 / 2012$ & $51^{\circ} 58^{\prime} 37.1^{\prime \prime}$ & $18^{\circ} 56^{\prime} 01.9^{\prime \prime}$ & 562 \\
\hline ERC & ETH Bioenergy & Caçu & $10 / 03 / 2011$ & $11 / 07 / 2012$ & $51^{\circ} 00^{\prime} 16.0^{\prime \prime}$ & $18^{\circ} 48^{\prime} 23.0^{\prime \prime}$ & 476 \\
\hline UGA & Goianésia mill & Goianésia & $15 / 07 / 2011$ & $22 / 08 / 2012$ & $49^{\circ} 04^{\prime} 28.7^{\prime \prime}$ & $15^{\circ} 08^{\prime} 43.9^{\prime \prime}$ & 734 \\
\hline UCA & Centroálcool mill & Inhumas & $13 / 05 / 2011$ & $30 / 06 / 2012$ & $49^{\circ} 33^{\prime} 11.1 "$ & $16^{\circ} 15^{\prime} 26.8^{\prime \prime}$ & 860 \\
\hline EMV & ETH Bioenergy & Mineiros & $23 / 02 / 2011$ & $16 / 09 / 2012$ & $53^{\circ} 00^{\prime} 12.2^{\prime \prime}$ & $17^{\circ} 44^{\prime} 00.2^{\prime \prime}$ & 810 \\
\hline UTB & Tropical Bioenergy & Porteirão & $30 / 06 / 2011$ & $04 / 09 / 2012$ & $50^{\circ} 00^{\prime} 51.6^{\prime \prime}$ & $17^{\circ} 28^{\prime} 52.3^{\prime \prime}$ & 492 \\
\hline UBV & Boa Vista mill & Quirinópolis & $11 / 02 / 2011$ & 09/08/2012 & $50^{\circ} 29^{\prime} 11.1^{\prime \prime}$ & $18^{\circ} 41^{\prime} 06.3^{\prime \prime}$ & 518 \\
\hline USF & São Francisco mill & Quirinópolis & $15 / 04 / 2011$ & $18 / 06 / 2012$ & $50^{\circ} 08^{\prime} 36.5^{\prime \prime}$ & $18^{\circ} 35^{\prime} 49.7^{\prime \prime}$ & 444 \\
\hline UCR & Cooper-Rubi mill & Rubiataba & $17 / 03 / 2011$ & $30 / 05 / 2012$ & $49^{\circ} 37^{\prime} 23.4^{\prime \prime}$ & $15^{\circ} 06^{\prime} 30.8^{\prime \prime}$ & 610 \\
\hline
\end{tabular}


$\left({ }^{\circ} \mathrm{C} \mathrm{d}^{-1}\right)$, maximum temperature $\left({ }^{\circ} \mathrm{C}^{-1}\right)$, minimum temperature $\left({ }^{\circ} \mathrm{C} \mathrm{d}^{-1}\right)$, mean temperature $\left({ }^{\circ} \mathrm{C} \mathrm{d}^{-1}\right)$, temperature range $\left({ }^{\circ} \mathrm{C} \mathrm{d}^{-1}\right)$, dew point $\left({ }^{\circ} \mathrm{C} \mathrm{d}^{-1}\right)$, wet bulb temperature $\left({ }^{\circ} \mathrm{C} \mathrm{d}^{-1}\right)$, atmospheric pressure $(\mathrm{kPa})$, top-of-atmosphere insolation $\left(\mathrm{MJ} \mathrm{m}^{-2} \mathrm{~d}^{-1}\right)$, in Table 2, registered from planting to harvest at each field trial, were used for environmental characterization. These data were obtained from the data base of the National Aeronautics and Space Administration Prediction of Worldwide Energy Resource (NASA POWER project 8) (Nasa Power, 2021), using the nasapower::get_ power() function.

Table 2. Environmental factors used to model genotype by environment interaction in cultivar field trials of sugarcane, in the state of Goiás, Brazil.

\begin{tabular}{lc}
\hline Environmental factor & Unit \\
\hline Rainfall & $\mathrm{mm} \mathrm{d}^{-1}$ \\
Relative humidity* & $\% \mathrm{~d}^{-1}$ \\
Earth skin temperature & ${ }^{\circ} \mathrm{C} \mathrm{d}^{-1}$ \\
Maximum temperature* & ${ }^{\circ} \mathrm{C} \mathrm{d}^{-1}$ \\
Minimum temperature* & ${ }^{\circ} \mathrm{C} \mathrm{d}^{-1}$ \\
Temperature* & ${ }^{\circ} \mathrm{C} \mathrm{d}^{-1}$ \\
Temperature range & ${ }^{\circ} \mathrm{C} \mathrm{d}^{-1}$ \\
Dew point* & ${ }^{\circ} \mathrm{C} \mathrm{d}^{-1}$ \\
Wet bulb temperature* & ${ }^{\circ} \mathrm{C} \mathrm{d}^{-1}$ \\
Atmospheric pressure & $\mathrm{kPa}^{\text {Top-of-atmosphere insolation }}$ \\
\hline
\end{tabular}

*Data measured at $2 \mathrm{~m}$ above ground.
For each trial, the crop growth cycle was divided into 10 phases with approximately the same duration (Table 3), and the mean of each environmental factor for each phase was calculated, resulting in 110 environmental covariates (EC). These ECs were coded with an ordinal number (1 to 10) between parentheses indicating the crop phase. Longitude, latitude and altitude were included in the data set, totaling $113 \mathrm{ECs}$. The 10 phases here defined correspond approximately to: 1 (germination), 2 (tillering), 3 to 8 (grand growth), and 9 to 10 (maturity).

Factorial regression (FR) was applied to select ECs as independent variables (regressors) to explain GEI, as follows:

$\mathrm{ge}_{\mathrm{ij}}=\sum_{\mathrm{h}=1}^{\mathrm{H}} \mathrm{b}_{\mathrm{ih}} \mathrm{Z}_{\mathrm{hj}}+(\mathrm{ge})_{\mathrm{ij}}^{\prime}$

where: $b_{i n}$ is the regression coefficient of the genotype $\mathrm{i}$ to the covariate $\mathrm{h}(\mathrm{h}=1,2, \ldots, \mathrm{H}) ; \mathrm{z}_{\mathrm{hj}}$ is the scaled value associated with the $\mathrm{EC} h$ in the location $\mathrm{j}$, given by $Z_{h j}=Z_{h j}-\bar{Z}$, where $Z_{h j}$ is the observed value, and $\bar{Z}$ is the mean of the "a" $Z_{j}$ values (for which " $a$ " is the number of tested environments); and (ge $)_{\mathrm{ij}}^{\prime}$ are the residual effects. Hence, the GEI effects are partitioned into a predictable portion, represented by the genotypic-sensitivity to some covariates (the first term of equation 3), and the unpredictable portion (ge)' not explained by the FR model.

Table 3. Duration of crop growth phases, in days, for each location where the sugarcane cultivar trials were carried out, in the state of Goiás, Brazil.

\begin{tabular}{|c|c|c|c|c|c|c|c|c|c|c|c|}
\hline \multirow[t]{2}{*}{ Location $^{(1)}$} & \multicolumn{10}{|c|}{ Crop growth phase } & \multirow{2}{*}{ Total } \\
\hline & 1 & 2 & 3 & 4 & 5 & 6 & 7 & 8 & 9 & 10 & \\
\hline EMV & 55 & 55 & 55 & 55 & 55 & 55 & 55 & 55 & 55 & 56 & 551 \\
\hline ERC & 49 & 49 & 49 & 49 & 49 & 49 & 49 & 49 & 49 & 49 & 490 \\
\hline UBV & 41 & 40 & 41 & 40 & 40 & 41 & 40 & 41 & 40 & 41 & 405 \\
\hline UCA & 42 & 41 & 42 & 41 & 41 & 42 & 41 & 42 & 41 & 42 & 415 \\
\hline UCR & 58 & 57 & 57 & 57 & 57 & 57 & 57 & 57 & 57 & 58 & 572 \\
\hline UGA & 44 & 43 & 43 & 43 & 43 & 44 & 43 & 43 & 43 & 44 & 433 \\
\hline UNA & 55 & 54 & 55 & 54 & 55 & 54 & 55 & 54 & 55 & 55 & 546 \\
\hline USF & 43 & 43 & 43 & 43 & 43 & 43 & 43 & 43 & 43 & 44 & 431 \\
\hline UTB & 44 & 44 & 44 & 44 & 44 & 44 & 44 & 44 & 44 & 45 & 441 \\
\hline Mean & 47.9 & 47.3 & 47.7 & 47.3 & 47.4 & 47.7 & 47.4 & 47.6 & 47.4 & 48.2 & 476 \\
\hline Cumulative sum & 47.9 & 95.2 & 142.9 & 190.2 & 237.7 & 285.3 & 332.8 & 380.3 & 427.8 & 476 & - \\
\hline
\end{tabular}

(1)UNA, at Nardini mill (Aporé, GO); ERC: at ETH Bioenergy, Rio Claro unit (Caçu, GO); UGA, at Goianésia mill (Goianésia, GO); UCA, at Centroálcool mill (Inhumas, GO); EMV, at ETH Bioenergy, Morro Vermelho unit (Mineiros, GO); UTB, at Tropical Bioenergy (Porteirão, GO); UBV, at Boa Vista mill (Quirinópolis, GO); USF, at São Francisco mill (Quirinópolis, GO); and UCR, at Cooper Rubi mill (Rubiataba, GO). 
The choice of ECs for modeling GEI was made by successive simple linear regression. At each cycle of the analysis, the sum of squares of the interaction, $\mathrm{SS}_{(\mathrm{ge})}$, associated with (g-1)(a-1) degrees of freedom, is partitioned into: linear effect of each $\mathrm{EC}, \mathrm{SS}_{z}$, associated with g-1 degrees of freedom, and a residual associated with (g-1)(a-2) degrees of freedom. Hence, at each cycle, the contribution of all covariates to the $\mathrm{SS}_{(\mathrm{ge})}$ were estimated separately. The EC explaining the largest proportion of the $\mathrm{SS}_{(\mathrm{ge})}$ was included in the deterministic part of the model (3), and (ge) $)_{\mathrm{ij}}$ was rewritten as $(\mathrm{ge})_{\mathrm{ij}}^{\prime}=(\mathrm{ge})_{\mathrm{ij}}-\mathrm{b}_{\mathrm{ih}} \mathrm{Z}_{\mathrm{hj}}$, which represents the GEI effect deducted from the linear effect of the selected covariate in that cycle (Figure 1). The cycles were repeated until no more covariates were significant at $\alpha=0.05$.

In this spatial analysis approach, thematic maps of genotypic adaptability were drawn based on the selected ECs. Hence, the yield adaptability of each genotype $i$ for a position $\mathrm{s}$, in the geographic gradient of the target region $\left(\mathrm{Ad}_{\mathrm{is}}\right)$, was calculated. The following estimator [adapted from Martins (2004)] was used

$\operatorname{Ad}_{\mathrm{is}}=\hat{\mathrm{g}}_{\mathrm{i}}+\Sigma_{\mathrm{k}=1}^{\mathrm{v}} \hat{\mathrm{b}}_{\mathrm{ih}} \mathrm{Z}_{\mathrm{hs}}$

where: $\hat{g}_{\mathrm{i}}$ is the estimated genotypic mean effect, obtained from the model (2); $\hat{b}_{\text {ih }}$ is the genotypicsensitivity coefficient to the EC $\mathrm{h}$ (here, $\mathrm{h}=1,2, \ldots, \mathrm{v}$ selected covariates, where $\mathrm{v} \leq \mathrm{H}$ ), that is, the estimate of from the model (3); and $\mathrm{z}_{\mathrm{hs}}$ is the normalized value of the covariate $h$, in a position s (pixel) over a geographic gradient. This step was implemented using the $\mathrm{R}$ function raster::calc( ).
In order to obtain data for the selected covariates over the geographic area of state of Goiás, the following steps were taken: first, a global grid of $0.5^{\circ} \times 0.5^{\circ}$ was generated (the maximum resolution available from the Nasa Power project 8); second, the global grid was cropped at the borders of the target territory, and the coordinates of each pixel were extracted; third, daily estimates for the selected covariates were obtained for those coordinates. The vector data of Goiás borders (shapefile) was obtained using the rnaturalearth::ne states( ) function. The previous steps used functions from the raster package: $\operatorname{raster}(), \operatorname{crop}(), \operatorname{mask}()$, values( ) and rasterToPoints( ).

To avoid bias on the values of ECs due to differences in planting and harvesting dates among trials (consequently, for cycle phases), we adopted the following steps: first, daily estimates for the selected covariates, over the target grid, were obtained; second, an average grid considering the days of each phase for each trial was obtained, totaling nine average grids for each covariate; and, third, the mean of the nine grids were used to compute.

Classes of yield adaptability were attributed empirically, with negative adaptabilities, represented by the red color, implying unfavorable genotypic performance. The range of positive yield adaptabilities were split into five classes of equal length, represented by the yellow, green, cyan, blue, and purple colors, such that purple indicates the highest incorporation of positive GEI effects into the genotype performance.

Finally, all the genotype maps were overlaid, and the genotype with the highest yield adaptability for each pixel in the grid was selected. The result was a map of



Figure 1. Diagram representing the successive simple linear regressions done, where $\mathrm{Y}$ is the interaction GE, and $\mathrm{x}_{\mathrm{h}}$ is the covariate $\mathrm{h}(\mathrm{h}=1,2, \ldots, \mathrm{H})$. 
winner genotypes for each spot in the gradient, which may guide the recommendation of the best genotype for each region.

\section{Results and Discussion}

Eleven environmental factors were used for ten crop stages, plus geographic coordinates and altitude, for analyzing the role that ECs played in GEI in sugarcane. Yield adaptability maps were built based on genotypicsensitivity coefficients related to selected predictive ECs, over a grid covering the state of Goiás.

Genotypic (G), environmental (E), and GEI effects were significant and accounted for $13.1 \%, 47.8 \%$ and $13.9 \%$ of the sum of squares (SS), respectively (Table 4). This agrees with findings from previous studies on sugarcane, carried out in South Africa, by which a significant portion of SS were due to GEI effects (Ramburan et al., 2011, 2012).

The fact that GEI effects showed similar magnitude, in comparison with the genotypic main effects, indicates an opportunity to explore the differential genotypic performance across environments. Modeling GEI for explicit environmental factors is useful to predict genotypic performances across a target population of environments (TPE), and it allows of the maximization of yield efficiency (Vargas et al., 1999; Ramburan et al., 2011, 2012; Costa-Neto et al., 2020).
Several open-access databases offer climate and elevation data worldwide (Hyman et al., 2013). Detailed environmental characterization with different types of data will play an important role in the understanding of the following issues: the drivers of phenotypic response $(\mathrm{Xu}, 2016)$; the differential performance of genotypes across a wide and variable TPE (Costa-Neto et al., 2020); and the definition of breeding targets (Resende et al., 2020).

In the present study, the first cycle of analyses showed that 68 out of 113 ECs were significant (Table 4). The covariate with the strongest association with GEI was longitude, which explained $30.8 \%$ of the $\mathrm{SS}_{(\mathrm{ge})}$. Hence, longitude was included in the model of the phenotypic response of recoverable sugar yield (YRS).

Afterward, its linear effect was removed from the $\mathrm{SS}_{(\mathrm{ge})}$ and the residual was regressed on the remaining covariates. In the second cycle of analyses, maximum temperature at phase 4 (beginning of sugarcane grand growth) was the EC that explained most of the residual $\mathrm{SS}_{(\mathrm{ge})}$ (Table 4). This factor ranged between sites from 28.5 to $38.8^{\circ} \mathrm{C}$. The optimum temperature for sugarcane growth is between 30 and $34^{\circ} \mathrm{C}$; and temperatures below $9^{\circ} \mathrm{C}$, or above $45^{\circ} \mathrm{C}$, inhibit the crop growth (Keating et al., 1999).

In the third cycle of the analysis, the average temperature at growth phase 1 (germination) was selected. Although the residual GEI was still significant, no covariate was significant in the fourth

Table 4. Analysis of variance for yield of recoverable sugar $\left(\mathrm{Mg} \mathrm{ha}^{-1}\right)$ in cultivar field trials of sugarcane, with partitioning of the genotype by environment interaction, considering the linear effects of environmental covariates.

\begin{tabular}{|c|c|c|c|c|c|c|}
\hline Source of variation & $\mathrm{DF}^{(4)}$ & $\mathrm{SS}^{(5)}$ & $\mathrm{MS}^{(6)}$ & $\mathrm{F}^{(7)}$ & $\operatorname{Pr}>F^{(8)}$ & $\% \mathrm{SS}_{\mathrm{ge}}{ }^{(9)}$ \\
\hline Genotype (G) & 25 & 584.03 & 23.36 & 15.08 & $<0.0001$ & \\
\hline Environment (E) & 8 & 2134.06 & 266.76 & 172.24 & $<0.0001$ & - \\
\hline GE interaction & 176 & 619.86 & 3.52 & 2.69 & $<0.0001$ & \\
\hline Longitude & 25 & 190.77 & 7.63 & 4.93 & $<0.0001$ & 30.78 \\
\hline GE residue & 151 & 429.08 & 2.84 & 1.83 & $<0.0001$ & \\
\hline Maximum temperature $(4)^{(1)}$ & 25 & 92.65 & 3.71 & 2.39 & $<0.0001$ & 14.95 \\
\hline GE residue & 126 & 336.43 & 2.67 & 1.72 & $<0.0001$ & \\
\hline Average temperature $(1)^{(2)}$ & 25 & 73.00 & 2.92 & 1.89 & 0.0058 & 11.78 \\
\hline GE residue & 101 & 263.43 & 2.61 & 1.68 & $<0.0001$ & \\
\hline Relative humidity $(7)^{(3)}$ & 25 & 48.01 & 1.92 & 1.24 & 0.1945 & - \\
\hline GE residue & 76 & 215.41 & 2.83 & 1.83 & $<0.0001$ & \\
\hline Pooled error / $\mathrm{r}$ & 727 & 1125.94 & 1.55 & - & - & \\
\hline
\end{tabular}

${ }^{(1)}$ Maximum temperature at crop stage 4. ${ }^{(2)}$ Average temperature at crop stage 1. ${ }^{(3)}$ Relative humidity at crop stage $7 .{ }^{(4)}$ Degree of freedom. ${ }^{5}$ Sum of squares. ${ }^{(6)}$ Mean square. ${ }^{(7)} \mathrm{F}$-test. ${ }^{(8)} \mathrm{p}$-value associated with the F statistic. ${ }^{(9)}$ Percentage of sum squares of the GE interaction explained by each covariable in that cycle. 
cycle of regression. Hence, the three selected covariates accounted for $57 \%$ of the variation of the $\mathrm{SS}_{(\mathrm{ge})}$.

Ramburan et al. (2011) studied the GEI in sugarcane, in South Africa, and they correlated environmental factors to scores derived from the principal component analysis (PCA). These authors found that harvest age, temperature, and water stress indices were the main environmental factors explaining GEI for sugar yield. In our study, the largest rainfall variation between locations was observed at the growth phase 1. Precipitation was significant in the first cycle; however, when longitude was included in the model, it was no longer significant.

FR models allow a GEI interpretation in a biological context, given by the estimation of the genotypic sensitivity to explicit ECs, instead of describing GEI as a differential reaction to hypothetical environmental differences (Malosetti et al., 2013; van Eeuwijk et al.,
2016). Hence, our approach allows the prediction of genotypic performance across a continuous geographic gradient, for sugarcane and other crops, and gives a better understanding of genotypic behavior, despite the environmental factors, throughout a target region.

The genotypic-sensitivity coefficients were summarized, representing the differential behavior of genotypes to selected ECs, in the form of maps of yield adaptability (Figure 2).

Within the context of plant breeding, environmental factors can be classified as predictable and unpredictable. Predictable factors include permanent characteristics of the environment or those varying in a systematic way (for instance, geographic coordinates, soil type, climatic normals). Unpredictable factors represent random fluctuations of environmental factors (such as rainfall and temperature). Thus, modeling GEI effects based on a set of more predictable factors could

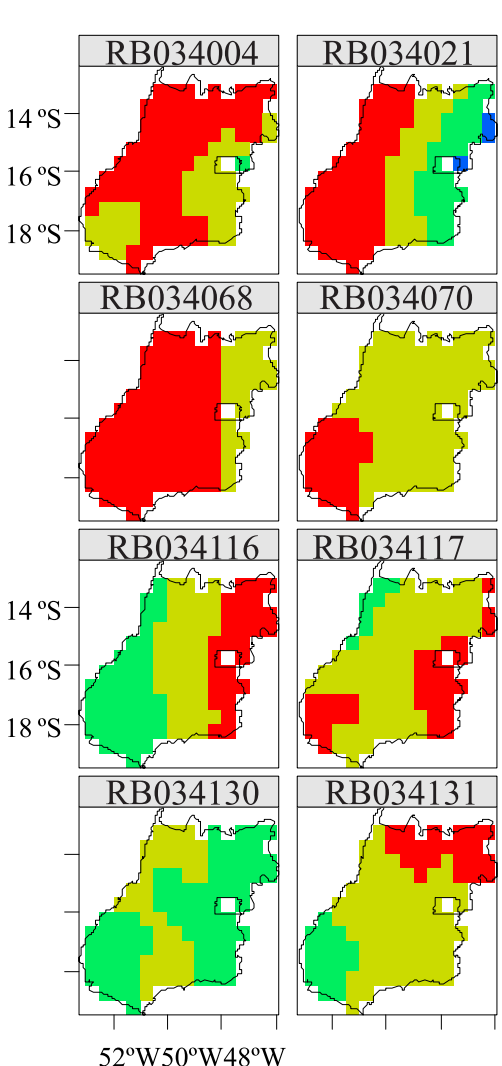

$52^{\circ} \mathrm{W} 50^{\circ} \mathrm{W} 48^{\circ} \mathrm{W}$



$52^{\circ} \mathrm{W} 50^{\circ} \mathrm{W} 48^{\circ} \mathrm{W}$



Longitude
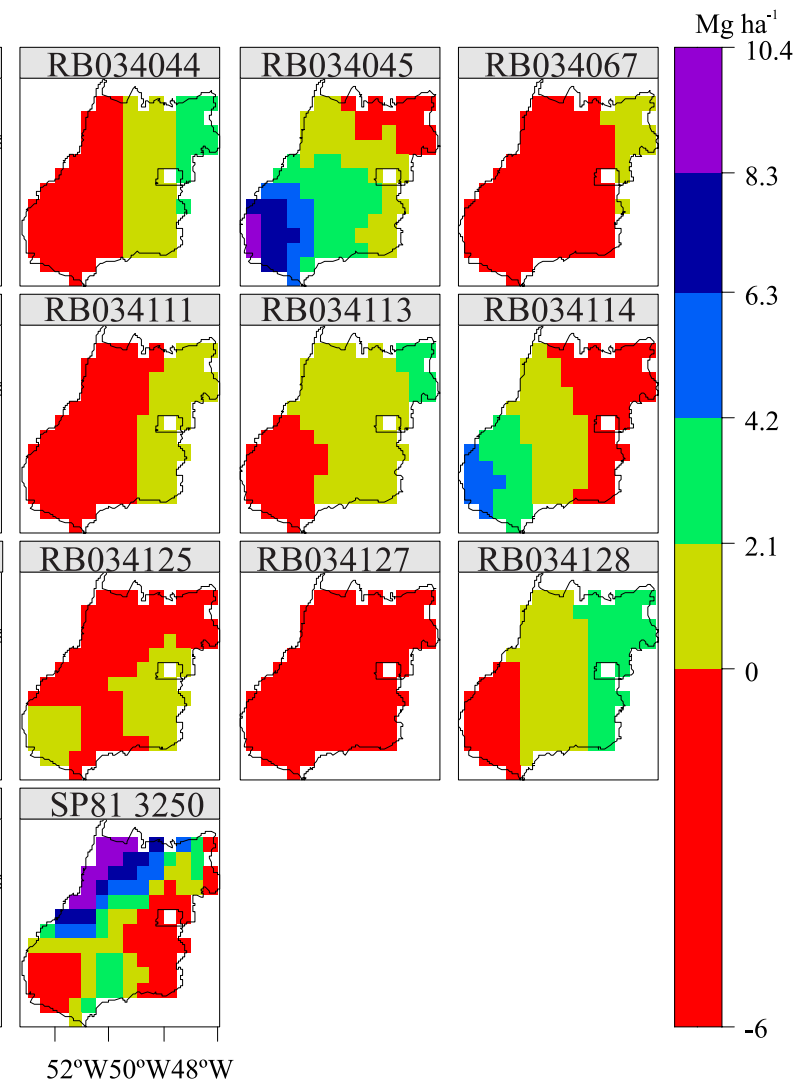

.2

1

$52^{\circ} \mathrm{W} 50^{\circ} \mathrm{W} 48^{\circ} \mathrm{W}$

Figure 2. Yield adaptability $\left(\mathrm{Ad}_{\mathrm{is}}\right)$ maps of sugarcane genotypes and check cultivars in the state of Goiás, Brazil, for recoverable sugar, based on the genotypic mean effect $\left(\hat{g}_{\mathrm{i}}\right)$ plus genotype-environment interaction captalized on each genotype, via its differential sensitivity $\left(\hat{b}_{i h}\right)$ to the environmental covariates, such as longitude, average temperature at crop germination phase, and maximum temperature at the beginning of grand growth phase. 
provide more accurate diagnosis of the genotypic adaptability and could be of more practical use for cultivar recommendation.

The check cultivars RB867515 and SP81 3250 along with the candidate clone RB034130 and the cultivar RB034045 showed better yield adaptability (Figure 2). For those genotypes, on most points in the grid, the environmental factors capitalized on the main genotypic effects (non-red pixels). There is evidence that south and southwest Goiás state tend to capitalize on the performance of the genotypes evaluated. Diversely, in the far northeast of the state, the majority of the genotypes did not show good performance. However, the candidate clones RB034128 and RB034021 showed specific adaptability in that area, contrasting with the performance shown by the checks (RB867515 and SP81 3250) and other candidate clones.

Overlapping the yield adaptability maps of all genotypes, the "winner genotype" was identified in each pixel of the grid (Figure 3 A). The winner genotype represents genotypes which showed higher yield adaptability in each pixel of the region. As expected from their high quality, the check cultivars RB867515 and SP81 3250 showed the highest yield estimates in most of the territory. The RB867515 check cultivar was superior in $35 \%$ of the pixels in the target region, especially in the southwest of the state, whereas SP81 3250 check cultivar showed superiority in 21\% of the pixels, mostly in the northwest region. The candidate clone RB034128 stood out in the northeast region, winning in $9 \%$ of the pixels, displaying specific adaptation to that region. The clone RB034021 showed superiority in the southeast of the state. Hence, those clones showed different adaptations, in comparison to those of the check cultivars, which is an opportunity to increase YRS in those regions using different genotypes.

When excluding both check cultivars (RB867515 and SP81 3250), the cultivar RB034045 appears as a promising alternative for a large area in the center and southwest regions of the state (Figure $3 \mathrm{~B}$ ). The RB034045 cultivar could share planting area with the check cultivar RB867515 in that region, with minimum compromise on YRS, diversifying genotypes grown in the state and conferring more resilience to the crop landscape. Other clones that show promise are RB034116 and RB034130.
The recommendation of different genotypes for a growing region is important to mitigate the risk of susceptibility to biotic and abiotic stresses (Annicchiarico et al., 2006). For sugarcane, some researchers suggest that the leading cultivar in a region should not exceed $25 \%$ of the total planting area (Zhao $\& \mathrm{Li}, 2015)$. As an example, around the year 2000, the genotype Q124 accounted for 45\% of Australia's sugarcane planting area. Although this genotype was described as resistant to orange rust (Puccinia kuehnii), a severe outbreak of this disease, caused by a new race of the pathogen, resulted in considerable
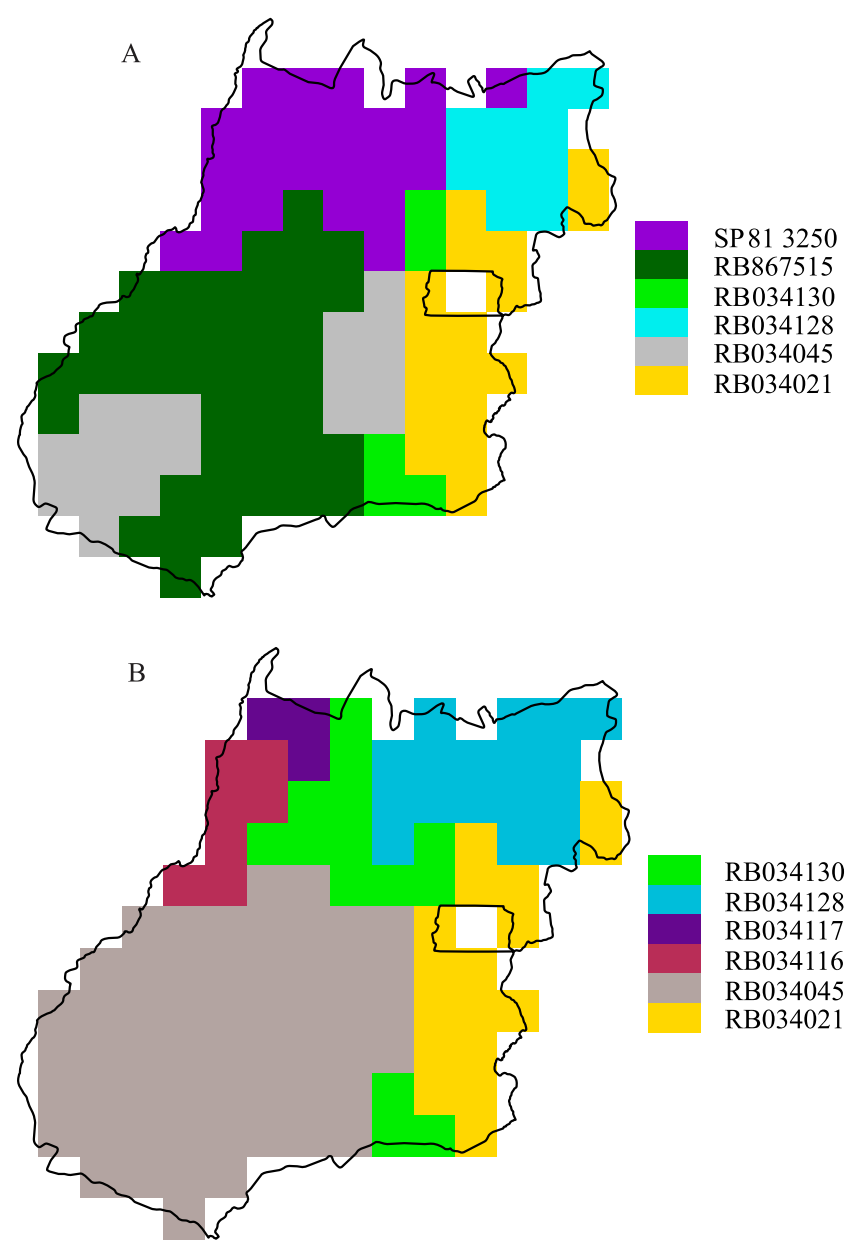

Figure 3. Geographic representation of the sugarcane genotypes with highest estimates of yield adaptability ("winner genotypes") for recoverable sugar $(\mathrm{Mg})$, in the state of Goiás, Brazil. The maps are from the analyses with (A) or without (B) the SP81 3250 and RB867515 check cultivars. 
financial losses to the sugarcane growers (Braithwaite et al., 2009).

Some regions in the state of Goiás have the possibility of increasing the efficiency of sugar production by exploiting GEI. For instance, RB034045 (cultivar), RB034116, and RB034130 have potential for sharing sugarcane growing area in this region with the RB867515 check cultivar.

When a hypothetical generalized use of the RB867515 check cultivar across the state is compared with that of winner genotypes (Figure $3 \mathrm{~A}$ ), there is, on average, an increase of $1.85 \mathrm{Mg} \mathrm{ha}^{-1}$ of YRS, which shows the benefit of exploring specific genotype adaptation. When compared to the SP81 3250 check cultivar, the use of specific genotypes taking into account GEI could increase YRS in $3.46 \mathrm{Mg} \mathrm{ha}^{-1}$. The clones RB034021 and RB034128 showed better adaptation to the northern and eastern parts of the state of Goiás, providing gains up to $4.6 \mathrm{Mg} \mathrm{ha}^{-1}$ on YRS in these regions. The RB034045 cultivar could share their growing area with RB867515 check cultivar, considering that it is well adapted to the same region, thus mitigating risks related to biotic and abiotic stresses (Figure 3).

\section{Conclusions}

1. Longitude, average temperature at crop germination phase and maximum temperature at beginning of the grand growth phase of sugarcane are the covariates which contributed most to the sum of squares of the GE interaction.

2. The RB034128 and RB034021 clones show promissing yield specific adaptations.

3. The RB034045 cultivar can share growing area with the check cultivar RB867515.

4. The factorial regression models coupled with the geographical information system represent a simple and efficient tool for the recommendation of sugarcane cultivars.

\section{Acknowledgments}

To Coordenação de Aperfeiçoamento de Pessoal de Nível Superior (Capes, Finance Code 001), for granting scholarship to Rafael Ferreira Montes.

The environmental data were obtained from the National Aeronautics and Space Administration (NASA) Langley Research Center (LaRC) Prediction of Worldwide Energy Resource (POWER) Project funded through the NASA Earth Science/Applied Science Program.

\section{References}

ANNICCHIARICO, P.; BELLAH, F.; CHIARI, T. Repeatable genotype $\mathrm{x}$ location interaction and its exploitation by conventional and GIS-based cultivar recommendation for durum wheat in Algeria. European Journal of Agronomy, v.24, p.70-81, 2006. DOI: https://doi.org/10.1016/j.eja.2005.05.003.

BRAITHWAITE, K.S.; CROFT, B.J.; MAGAREY, R.C.; SCHARASCHKIN, T. Phylogenetic placement of the sugarcane orange rust pathogen Puccinia kuehnii in a historical and regional context. Australasian Plant Pathology, v.38, p.380-388, 2009. DOI: https://doi.org/10.1071/AP09012.

COSTA-NETO, G.M.F.; MORAIS JÚNIOR, O.P.; HEINEMANN, A.B.; CASTRO, A.P. de; DUARTE, J.B. A novel GIS-based tool to reveal spatial trends in reaction norm: upland rice case study. Euphytica, v.216, art.37, 2020. DOI: https://doi.org/10.1007/ s10681-020-2573-4.

GUILLY, S.; DUMONT, T.; THONG-CHANE, A.; BARAU, L.; HOARAU, J.-Y. 2017. Analysis of multienvironment trials (MET) in the sugarcane breeding program of Réunion Island. Euphytica, v.213, art.213, 2017. DOI: https://doi.org/10.1007/s10681-017-19941 .

HIJMANS, R.J. Raster: geographic data analysis and modeling. $\mathrm{R}$ version 2.5-8: R package. Vienna: R Foundation for Statistical Computing, 2016. Available at: <https://rdrr.io/cran/raster/>. Accessed on: June 302020.

HØJSGAARD, S.; HALEKOH, U. doBY: groupwise statistics, LSmeans, linear contrasts, utilities. $\mathrm{R}$ version 4.5-15: $\mathrm{R}$ package. Vienna: R Foundation for Statistical Computing, 2016. Available at: <https://rdrr.io/cran/doBy/>. Accessed on: Sept. 232020.

HYMAN, G.; HODSON, D.; JONES, P. Spatial analysis to support geographic targeting of genotypes to environments. Frontiers in Physiology, v.4, art.40, 2013. DOI: https://doi.org/10.3389/ fphys.2013.00040.

KEATING, B.A.; ROBERTSON, M.J.; MUCHOW, R.C.; HUTH, N.I. Modelling sugarcane production systems I: Development and performance of the sugarcane module. Field Crops Research, v.61, p.253-271, 1999. DOI: https://doi.org/10.1016/S03784290(98)00167-1.

LAMIGUEIRO, O.P.; HIJMANS, R.J. Meteoforecast. R version 0.41: R package.Vienna: R Foundation for Statistical Computing, 2016. Available at: <https://cran.r-project.org/web/packages/ meteoForecast/index.html>. Accessed on: Oct. 112020.

MALOSETTI, M.; RIBAUT, J.-M.; VAN EEUWIJK, F.A. The statistical analysis of multi-environment data: modeling genotype-by-environment interaction and its genetic basis. Frontiers in Physiology, v.4, art. 44, 2013. DOI: https://doi.org/10.3389/fphys.2013.00044.

MANZATTO, C.V.; ASSAD, E.D.; BACA, J.F.M.; ZARONI, M.J.; PEREIRA, S.E.M. (Org.). Zoneamento agroecológico da 
cana-de-açúcar: expandir a produção, preservar a vida, garantir o futuro. Rio de Janeiro: Embrapa Solos, 2009. (Embrapa Solos. Documentos, 110). Available at: <https:/ainfo.cnptia.embrapa.br/ digital/bitstream/CNPS-2010/14408/1/ZonCana.pdf $>$. Accessed on: Nov. 172020.

MARTINS A.S. Aplicação de sistema de informações geográficas no estudo da interação genótipos com ambientes. 2004. 312p. Dissertação (Mestrado) - Universidade Federal de Goiás, Goiânia.

NASA POWER. National Aeronautics and Space Administration Prediction of Worldwide Energy Resource. NASA POWER project 8. Available at: <https://www.power.larc. nasa.gov/>. Accessed on: Oct. 12021.

PIMENTEL-GOMES, F. Curso de estatística experimental. 15.ed. Piracicaba: Esalq, 2009. 451p.

R CORE TEAM. R: a language and environment for statistical computing. Vienna: R Foundation for Statistical Computing, 2016. Available at: <https://www.R-project.org/>. Accessed on: July 202019.

RAMBURAN, S.; ZHOU, M.; LABUSCHAGNE, M. Integrating empirical and analytical approaches to investigate genotype $\times$ environment interactions in sugarcane. Crop Science, v.52, p.21532165, 2012. DOI: https://doi.org/10.2135/cropsci2012.02.0128.

RAMBURAN, S.; ZHOU, M.; LABUSCHAGNE, M. Interpretation of genotype $\times$ environment interactions of sugarcane: identifying significant environmental factors. Field Crops Research, v.124, p.392-399, 2011. DOI: https://doi.org/10.1016/j.fcr.2011.07.008.

RESENDE, R.T.; PIEPHO, H.-P.; ROSA, G.J.M.; SILVA-JUNIOR, O.B.; SILVA, F.F. e; RESENDE, M.D.V. de; GRATTAPAGLIA, D. Enviromics in breeding: applications and perspectives on envirotypic-assisted selection. Theoretical and Applied Genetics, v.134, p.95-112, 2020. DOI: https://doi.org/10.1007/ s00122-020-03684-z.

RIDESA. Rede Interuniversitária para o Desenvolvimento do Setor Sucroenergético. Available at: <https://www.ridesa.com. br>. Accessed on: Oct. 2021.

SILVEIRA, L.C.I. da; KIST, V.; PAULA, T.O.M. de; BARBOSA, M.H.P.; PETERNELLI, L.A.; DAROS, E. AMMI analysis to evaluate the adaptability and phenotypic stability of sugarcane genotypes. Scientia Agricola, v.70, p.27-32, 2013. DOI: https://doi.org/10.1590/S0103-90162013000100005.

SOUTH, A. Rnaturalearth: world map data from natural Earth. $\mathrm{R}$ package version 0.1.0. Vienna: R Foundation for Statistical
Computing, 2017. Available at: <https://cran.r-project.org/web/ packages/rnaturalearth/rnaturalearth.pdf $>$. Accessed on: July 21 2020.

SPARKS, A.H. Nasapower: a NASA POWER global meteorology, surface solar energy and climatology data client for R. Journal of Open Source Software, v.3, art.1035, 2018. DOI: https://doi.org/10.21105/joss.01035.

TODD, J.; PAN, Y.-B.; KIMBENG, C.; DUFRENE JR., E.; WAGUESPACK JR., H.; PONTIF, M. Analysis of genotype by environment interaction in Louisiana sugarcane research plots by GGE biplots. Sugar Tech, v.20, p.407-419, 2018. DOI: https://doi.org/10.1007/s12355-017-0565-Z.

VAN EEUWIJK, F.A.; BUSTOS-KORTS, D.V.; MALOSETTI, M. What should students in plant breeding know about the statistical aspects of genotype $\times$ environment interactions? Crop Science, v.56, p.2119-2140, 2016. DOI: https://doi.org/10.2135/ cropsci2015.06.0375.

VAN EEUWIJK, F.A.; DENIS, J.B.; KANG, M.S. Incorporating additional information on genotypes and environments in models for two-way genotype by environment tables. In: KANG, M.S.; GAUCH JR., H.G. (Ed.). Genotype-by-environment interaction. Boca Raton: CRC Press, 1996. cap.2, p.15-49. DOI: https://doi.org/10.1201/9781420049374.ch2.

VARGAS, M.; CROSSA, J.; VAN EEUWIJK, F.A.; RAMÍRES, M.E.; SAYRE, K. Using partial least squares regression, factorial regression, and AMMI models for interpreting genotype $\times$ environment interaction. Crop Science, v.39, p.955-967, 1999. DOI: https://doi.org/10.2135/cropsci1999.0011183X003900040002x.

WICKHAM, H.; AVERICK, M.; BRYAN, J.; CHANG, W.; MCGOWAN, L.D.; FRANÇOIS, R.; GROLEMUND, G.; HAYES, A.; HENRY, L.; HESTER, J.; KUHN, M.; PEDERSEN, T.L.; MILLER, E.; BACHE, S.M.; MÜLLER, K.; OOMS, J.; ROBINSON, D.; SEIDEL, D.P.; SPINU, V.; TAKAHASHI, K.; VAUGHAN, D.; WILKE, C.; WOO, K.; YUTANI, H. Welcome to the Tidyverse. Journal of Open Source Software, v.4, art.1686, 2019. DOI: https://doi.org/10.21105/joss.01686.

XU, Y. Envirotyping for deciphering environmental impacts on crop plants. Theoretical and Applied Genetics, v.129, p.653-673, 2016. DOI: https://doi.org/10.1007/s00122-016-2691-5.

ZHAO, D.; LI, Y.-R. Climate change and sugarcane production: potential impact and mitigation strategies. International Journal of Agronomy, v.2015, art.547386, 2015. DOI: https://doi.org/10.1155/2015/547386. 